\title{
The Study of Serum Complement C3, C4 and Immunoglobulin E IgE in Psoriasis Patients
}

\author{
Hind Y. khalaf* \\ Talib A. Hussein* \\ Basman M. fadheel ${ }^{* *}$ \\ *Department of Biology, College of Science for Women, University of Baghdad \\ $* *$ College of Medicine, University of Baghdad
}

Received 24, November, 2014

Accepted 5, January, 2015

(c) $($ ) $\Theta \Theta$

NoDerivatives 4.0 International Licens

\section{Abstract:}

The present study was aimed to find out the role of humoral immunity in the pathogenesis of psoriasis. Complements $\mathrm{C} 3, \mathrm{C} 4$ and immunoglobulin IgE .The study included 55 Iraqi patients with psoriasis 30 (15 females, 15 males) were untreated with any drugs. The other patient group consisted of 25 (9 female and 16 male) treated with a biological treatment (infliximab) , and 30 (13 males ,12 females) healthy control group. Blood sample were withdrawn (5) $\mathrm{ml}$ of venous blood for both patients and members of the control ,to conduct the Immunological tests to determine the quantitative for each of total IgE by using (ELISA) and C3,C4 by Single Radial Immunodiffuse (SIRD). The results showed significant increase in the level of probability $(\mathrm{P}<0.05)$ in the rate of total $\mathrm{IgE}$ immunoglobulin and $\mathrm{C} 3$ in patients compared to the control (healthy).As well as the result also showed no significant increases of $\mathrm{C} 4$. From this we can deduce that elevation of total serum IgE is associated with psoriasis. Alternate pathway is a way of complement in pathogenesis of psoriasis.

Key words: Psoriasis, C3, C4, IgE.

\section{Introduction:}

Psoriasis is a chronic inflammatory skin disease, affecting approximately $(2-3 \%)$ of the world's population, it is more common in Caucasians, it can affect any race and can occur at any age and recognized by change proliferation and differentiation keratinocytes. [1,2]. Psoriasis is a related with inflammation and scaling of skin. The cells of the skin come on surface quickly before their complete maturation. [3].

It is characterized by sharply demarcated erythematous plaques with silvery scales, this disease may effect skin in anywhere on the body, and it appears on many parts of the body especially on the parts of legs (elbows, knees). Palms, and soles of the feet, face, scalp, lower back. Its diversity in severity from a little dispersed red, to plaques covered with scales to all entire body surface. It progressively worsen with associated with age, and wane in its severity, the degree of severity reliance on many factors includes inheritance and environmental factors [4]. Clinically a spectrum of different subtypes may be observed: psoriasis vulgaris, guttate psoriasis, erythrodermic psoriasis, pustular psoriasis, inverse psoriasis, and arthritis. [5]. 
The evidence indicated the Genetic, environmental, and immunological factors contribute to the pathogenesis of psoriasis and play important roles in its development. Other factors lead to cause psoriasis including infections (bacteria and virus), stress, smoking, alcohol and medications, the most common medications know to trigger existing psoriasis including (antimalarial agent, gold salts, lithium and beta blockers), the letter lead to aggravation psoriasis. [6].

Increased level of immunoglobulin and circulating immune complexes and complements (C3, C4), have been mention in psoriasis diseases [7]. In psoriasis diseases noticed the effected skin synthesizes immunoglobulin (Ig) in different patterns whereas in normal skin was not found this synthesis [8] Complement compound $\mathrm{C} 3$ and $\mathrm{C} 4$ in the inflammatory process were found in high level as markers of inflammation [9].The aimed of this study is for measuring the level of total $\operatorname{IgE}$ antibody in the blood serum of patients with psoriasis by test RIST using adsorption mechanism linked immunosorbent assay (ELISA). The relationship between linking psoriasis and cytokines on the one side and the number of eosinophil on the other side as sensitive indicator and measure complement components $\mathrm{C} 3, \mathrm{C} 4$.

\section{Materials and Methods:}

\section{- $\quad$ Sample Study}

This study was carried out at the Department of Dermatology and Venereology in Baghdad Teaching Hospital Clinic during the period from November 2013 to April 2014. The study included 60 patients with psoriasis; their ages ranged from (6-70) years. The diagnosis by the medical staff at the clinic based on international criteria. Patients were distributed in two groups; the first group was the untreated group. It consist of 30 patients of both sexes (15 males and 15 females). The second group was the group that had a biological treatment (Inflximab). It consisted of 25 patients of both sexes (16 males and 9 females). The study also included 25 apparently healthy people of both sexes (13 males and 12 females). Who were matched patients by age (6-65) .

\section{- Collection of Blood Sample and Methods:-}

The blood sample was collected (5) $\mathrm{ml}$ from the venous blood of the patients of both groups and control group .Each model was deal with as flows: $5 \mathrm{ml}$ of blood was transferred to a plain tube and left to clot at room temperature for 30 minutes. Then, the samples were Centrifuged at speed 2500 RPM for 10 minutes. Then, the serum was collected by using micropipette to be later distributed in the three of the Eppendrof tubes, and kept at a temperature in deep freezer ( $20^{\circ}$ ) $\mathrm{C}$ to be later used. The level of total IgE was detected using (DRG, USA) by Enzyme Linked Immunoasorbent Assay (ELISA) technique kit and C3, C4 concentration by Single Radial Immunodiffuse (SIRD) human Germany, were measured. The statistical analysis the SAS program (2010) in the statistical analysis of the data for the study of the effect of the studied factors in different qualities, and compared the moral differences between the test averages less significant difference LSD [10].The results of total $\operatorname{IgE}$ was expressed by mean \pm standard errors also the concentration of $\mathrm{C} 3, \mathrm{C} 4$ components.

\section{Results:}

The patients of this study suffered from different types of psoriatic disease [plaque (vulgaris), guttate, pustular, erythrodermic and arthritis]. Most of them suffered from plaque psoriasis, figuer $(1,2)$. 


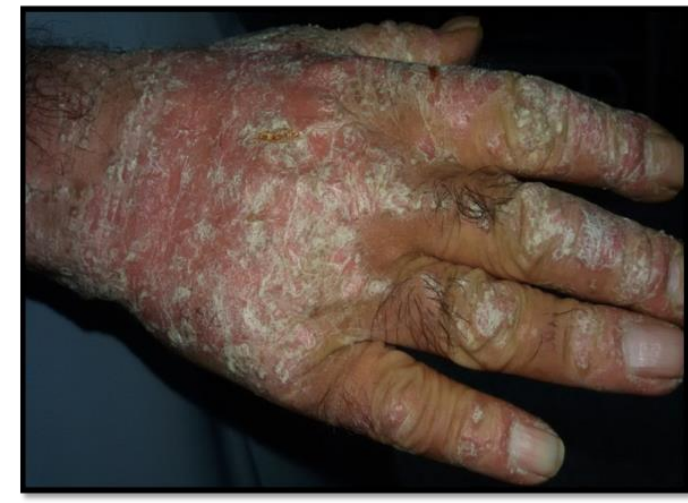

Fig (1): Psoriasis vulgaris in the hand

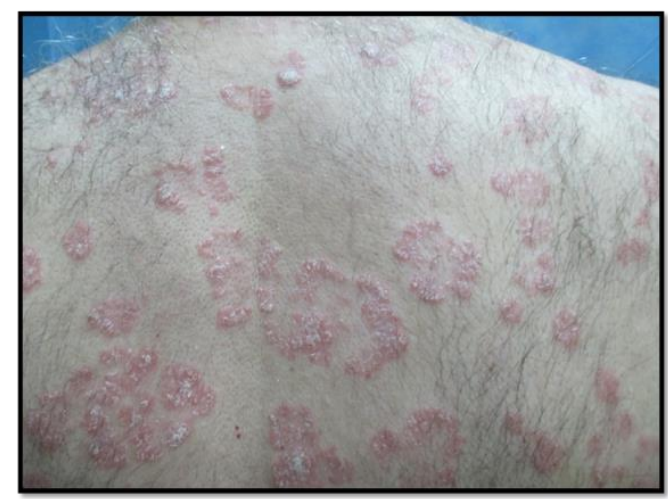

Fig (2): Psoriasis vulgaris in the Back

The patients treated with a biological treatment (Infliximab) administered as 3-5 mg/kg Intravenous (I.V.) infusion at time 0,2,4 and 6-weeks (induction) and every8-weeks maintenance, were asked to give blood sample through the period of taking the treatment. Most of them took about (4-6 dosages) through the period of study was monitored to find out the extent of the effect of the treatment (figurer 3;A,B)
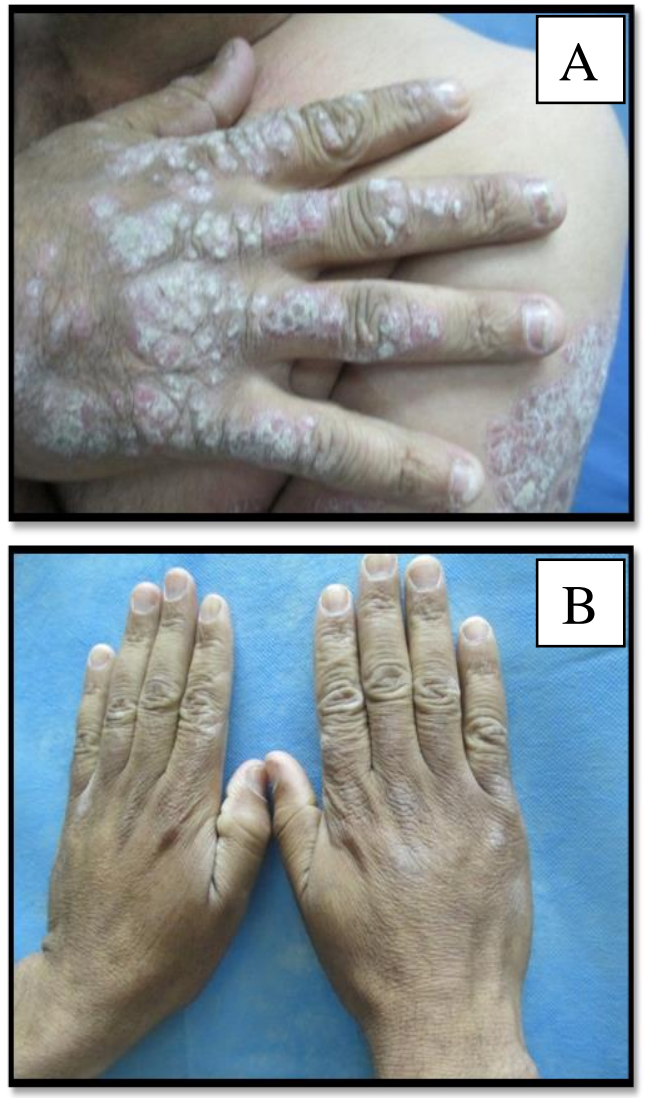

Fig (3):A-psoriasis patient before treatment, B-psoriasis patient after treatment with Infliximab

\section{The Third Component of the Complement (C3):}

The untreated and treated psoriasis patients showed an elevated mean serum level of C3 (138.61 7.25 and $132.38 \pm 6.49 \mathrm{mg} / \mathrm{dl}$, respectively) as compare with the healthy control $(123.37 \pm 4.38 \mathrm{mg} / \mathrm{dl})$.There was no significant $\quad(\mathrm{P}>0.05) \quad$ difference between patient groups. Further, there was a significant $(\mathrm{P}<0.05)$ difference between the untreated psoriasis patient groups and the healthy control. Besides, there was no significant $(\mathrm{P}>0.05)$ difference between the treated psoriasis patient group and the healthy control Table(1).

\section{The Fourth Component of Complement (C4):}

The mean serum level of $\mathrm{C} 4$ showed no significant difference $(\mathrm{P}>0.05)$ between the untreated and 
treated psoriasis patients when compared to the healthy control group, Table (2).

\section{Serum level of IgE:}

Untreated psoriasis patients showed an elevated mean in the serum level of $\operatorname{IgE}(48.77 \pm 10.0 \mathrm{IU} / \mathrm{ml} 1)$. This was Followed by patients treated with a biological treatment (Infliximab) whose mean serum level of IgE was $(29.91 \pm 8.38 \mathrm{IU} / \mathrm{ml})$. The lowest rate recorded in the healthy control group $(29.78 \pm 7.63 \mathrm{IU} / \mathrm{ml})$ of $\mathrm{IgE}$.

The results showed a significant difference in the sera of $\operatorname{IgE}$ mean levels between patient groups, whether untreated psoriasis patients and the patients treated with biological treatment, (Infliximab), $(48.77 \pm 10.01$ $\mathrm{IU} / \mathrm{ml}, \quad 29.91 \pm \quad 8.38 \quad \mathrm{IU} / \mathrm{ml}$ ,respectively $\mathrm{P}<0.05)$. There also was a significant difference in the sera of IgE mean levels between the untreated psoriasis patient and the healthy control group, $(48.77 \pm 10.01 \mathrm{IU} / \mathrm{ml}$, $29.78 \pm 7.63 \mathrm{IU} / \mathrm{ml}$, respectively $\mathrm{P}$ $>0.05$ ). Besides, there was no significant difference in the sera of $\operatorname{IgE}$ mean levels between the patients treated with a biological treatment (Infliximab) and the healthy control group $(29.91 \pm 8.38 \mathrm{IU} / \mathrm{ml}, 29.78 \pm$ $7.63 \mathrm{IU} / \mathrm{ml}$,respectively $\mathrm{P}>0.05)$, Table(3) .

Table (1): The Mean Serum Concentration of $\mathrm{C} 3 \mathrm{mg} / \mathrm{dl}$ in the Study groups

\begin{tabular}{|c|c|c|c|c|}
\hline \multicolumn{2}{|c|}{ Groups } & Number & $\begin{array}{c}\text { Mean } \pm \text { S.E. } \\
\text { C3 mg/dl }\end{array}$ & $\begin{array}{c}\text { LSD } \\
\text { Value }\end{array}$ \\
\hline \multirow{3}{*}{ Patients } & Group1 & 30 & $\begin{array}{c}138.61 \pm \\
7.25 * a\end{array}$ & \\
\cline { 2 - 4 } & Group2 & 25 & $\begin{array}{c}132.38 \pm \\
6.49 \text { ab }\end{array}$ & \multirow{1}{*}{$\begin{array}{c}12.086 \\
*\end{array}$} \\
\hline \multicolumn{2}{|c|}{ Control } & 25 & $\begin{array}{c}123.37 \pm \\
4.38 ~ b\end{array}$ & \\
\hline \multicolumn{4}{|c|}{$*(P \leq 0.05)$} \\
\hline
\end{tabular}

Table(2): The Mean Serum Concentration of $\mathrm{C} 4 \mathrm{mg} / \mathrm{dl}$ in Study groups

\begin{tabular}{|c|c|c|c|c|}
\hline \multicolumn{2}{|c|}{ Groups } & Number & $\begin{array}{c}\text { Mean } \pm \text { S.E. } \\
\text { C4 mg/dl }\end{array}$ & $\begin{array}{c}\text { LSD } \\
\text { Value }\end{array}$ \\
\hline \multirow[b]{2}{*}{ Patient } & Goup1 & 30 & $32.64 \pm 4.22 \mathrm{a}$ & \multirow{3}{*}{8.801} \\
\hline & Goup2 & 25 & $26.19 \pm 2.15 \mathrm{a}$ & \\
\hline \multicolumn{2}{|c|}{ Control } & 25 & $29.86 \pm 1.73 a$ & \\
\hline \multicolumn{5}{|c|}{ NS: Non-significant } \\
\hline
\end{tabular}

Table(3):The Mean Serum Concentration of IgE IU/ml in Study groups

\begin{tabular}{|c|c|c|c|c|}
\hline \multicolumn{2}{|c|}{ Groups } & Number & $\begin{array}{c}\text { Mean } \pm \text { S.E. } \\
\text { IgE IU/ml }\end{array}$ & $\begin{array}{l}\text { LSD } \\
\text { value }\end{array}$ \\
\hline \multirow[t]{2}{*}{ Patients } & Group1 & 30 & $\begin{array}{c}48.77 \pm \\
10.01^{*}\end{array}$ & \multirow{3}{*}{$\begin{array}{c}15.285 \\
*\end{array}$} \\
\hline & Group2 & 25 & $29.91 \pm 8.38$ & \\
\hline \multicolumn{2}{|c|}{ Control } & 25 & $29.78 \pm 7.63$ & \\
\hline \multicolumn{5}{|c|}{$*(P \leq 0.05)$} \\
\hline
\end{tabular}

\section{Discussion:}

Psoriasis is a common skin disease characterized by various immunological alterations. In the present study, serum complements and serum immunoglobulin level (IgE) were demonstrated in psoriasis patients compared to control group.

Earlier data concerning psoriasis patient related to $\mathrm{C} 3, \mathrm{C} 4$ serum concentration are significant elevation of C3. Besides, no significant elevation of $\mathrm{C} 4$ in the untreated psoriasis patients as compared with the healthy control. The result was an agreement with the result of [11], who noticed an increase level of C3 and normal levels of C4 in psoriasis patients as compared with the healthy control.

C3 derived from human keratinocyte contribute to epidermal basement membrane deposit of $\mathrm{C} 3$ in autoimmune or inflammatory skin disorder such as psoriasis and play major role in the pathogenesis [12]. The present result was disagree with the result of [13] they found that $\mathrm{C} 4$ levels were significantly increased.

The present result also showed decreases of $\mathrm{C} 3$ and $\mathrm{C} 4$ in patient treated with biological treatment (Infliximab) as compared with untreated psoriasis patients are 
compatible with result [14], who concluded that the levels of $\mathrm{C} 3$ and $\mathrm{C} 4$ fragments were significantly higher in the pretreated psoriasis group and low to normal levels following anti-TNF therapy. It was suggested to use complement levels to monitor antiTNF therapy.

Reports maintained the activation of the Complement system by the alternate pathway induced by bacterial infection, Streptococcus Group B. This further lead to the production of TNF, C3 and Factor B. Both components of the alternate pathway were needed for the increase in TNF release. TNF has great role in the pathogens of psoriasis. Infliximab anti-TNF therapy which has been proven to be effective reduces complement activation [15].

The current mentioned data suggests that the psoriasis patients have an increase in the serum of $\operatorname{IgE}$ concentrations in patients of about (48.77) and (29.78) in controls. This increase was statistically significant, this result agreement with result stated by [16] they referred to the significant elevated mean serum level of $\operatorname{IgE}$ concentration in the sera of patients compared with the healthy control groups.

The regulation mechanism of $\operatorname{IgE}$ synthesis, $\operatorname{IgE}$ is usually synthesis by Th2 cell determinate $[17,18]$. The single in needed for produce $\operatorname{IgE}$ involves Th2 cytokines IL-4 and IL-13. Keratinocytes do not produce IL-4 ol IL-13, but are important for IL-4 or IL13 to induced biological effects [19]. Hyper IgE in psoriasis, result by a shift from Th1 to Th2 and thought that warring should be taken in the use of Th2 inducing treatments in psoriasis [20].

\section{References:}

[1] Nickoloff, B.J. and Nestle, F.O. 2004. Recent insights into the immunopathogenesis of psoriasis provide new therapeutic opportunities. J Clin Invest. 113: 1664-1675

[2] Schon, M. P. and Boehncke, W. H. 2005. Psoriasis. N Engl J Med. 352: 899-912

[3] Mahesar, S. M.; Mahesar. H. and Khand, A. A. 2011. Quantitative and qualitative change in leukocytes of psoriatic. Pak J Physiol. 7(1):40-43.

[4] Lebwohl. M. 2003. Psoriasis. Lancet .361: 1197 - 1204

[5] Christophers, E. 2001. Psoriasis epidemiology and clinical spectrum. Clin Exp Dermatol.26: 314-20.

[6] Milavec-Puretić, V.; Mance, M.; Čeović, R.; and Lipozenčić, J. 2011. Drug Induced Psoriasis, Acta Dermato venerol Croat .19(1):39-42

[7] Kapp, A.; Wokalek, H. and Schopf, E.; 1984. Involvement of complement in psoriasis and atopic dermatitis - Measurement of C3a and C5a, C3, C4 and C1 inactivator. Arch Dermatol Res 1984; 277: 359-61.

[8] Lai A Fat RFM, Suurmond D, Furth RV. 1973. In vitro synthesis of immunoglobulin secretory component and complement innormal and pathological skin and adjacent mucous membranes. Clin Exp Immunol 14: 377.

[9] Rocha-Pereira, P.; Santos-Silva, A.; Rebelo, I.; Figueiredo, A.; Quintanilha, A. and Teixeira, F. 2004. The Inflammatory Response inMild and in Severe Psoriasis. $\mathrm{Br}$ J Dermatol .150:917-28.

[10]SAS. 2010. Statistical Analysis System, User's Guide. Statistical. Version 9.1 ${ }^{\text {th }}$ Ed. SAS. Inst. Inc. Cary. N.C. USA

[11]Weigl, B. A. 2000. The significance of stress hormones (glucocorticoids, catecholamines) for eruptions and spontaneous 
remission phases in psoriasis. Int $\mathbf{J}$ Dermatol 39: 678-88.

[12] Seguin, N.; Porneuf, M.; Dereure, V.; Tesnieres, A.; Yancey, K. B. and Guilhou, J. 1993.C3 d,j Deposition in inflammatory skin diseases: use of psoriatic skin as a model of cutaneous inflammation. The society for investigation Dermatology.101(6):827:831

[13] Singh, S.; Singh, U. and Singh, S. 2009. Study of serum Complement C3, C4 and Immunoglobulins IgG ,IgA, IgM in Psoriasis patients in North India. Indian J Allergy Asthma Immunol. 23(2) : 73-77.

[14]Chimenti, M. S.; Perricone, C.; Graceffa, D. G.; Di Muzio, E.; Ballanti, M.D.; Guarino, P.; Conigliaro, E.; Greco, B.; Kroegler Perricone, R. 2012. Complement system in psoriatic arthritis: a useful marker in response prediction and monitoring of anti-TNF treatment. Clin Exp Rheumatol. 30:23-30.

[15]Ballanti, E.; Pericone, C.; di Muzio, G.; Kroegler, B.; Chimenti, M. S.; Graceffa, D. and Pericone, R. 2011. Role of the complement system in rheumatoid arthritis and psoriatic arthritis: relationship with anti-TNF inhibitors. Autoimmun Rev .10: 617-623.

[16] Ovcina-Kurtovic, N. and Kasumagic-Halilovic, E. 2010. Serum Levels of Total Immunoglobulin E in Patients with Psoriasis: Relationship with Clinical Type of Disease. MED ARH.64(1) :28-29

[17]Geha, R. S.; Jabara, H. H. and Brodeur, S. R. 2003. The regulation of immunoglobulin $\mathrm{E}$ classswitchrecombination. Nat Rev Immunol, 3: 721-32.

[18]Bacharier, L. B. and Geha, R. S. 2000. Molecular mechanisms of $\mathrm{IgE}$ regulation. J Allergy Clin Immunol, . 105:547-58.

[19]Elbe-Burger, A.; Egyed, A.; Olt, S.; Klubal, R.; Mann, U.; Rappersberger, K. and et al. 2002. Overexpresion of IL-4 alters the homeostasis in the skin. J Invest Dermatol. 118: 767-778.

[20]Li, L. F.; Sujan, S. A.; Yang, H.; and Wang, W.H. 2005. Serum immunoglobulins in psoriatic erythroderma. Med Arch. 30(2): 125-7. 


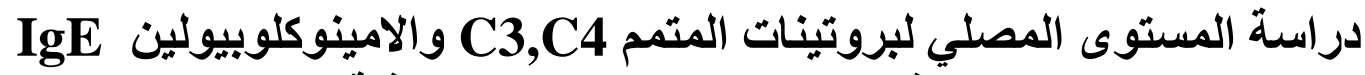 الكلي في مرضى مصابين بلاء الصنم الصدفية}

*بمان مدحت فضيل

* طالب عبد الله حسين

هند يوسف خلف

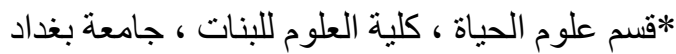

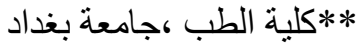

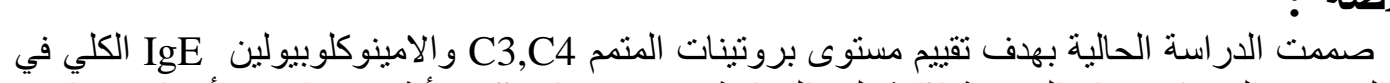

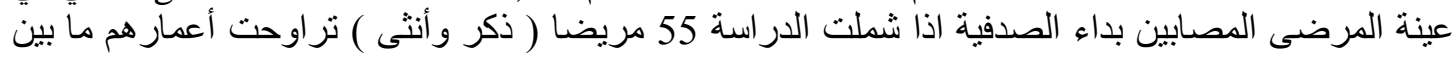

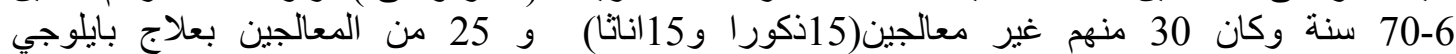
(16)Infliximab

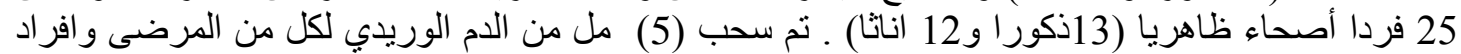

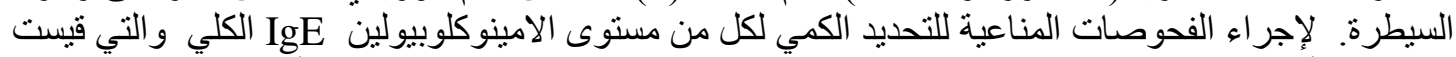

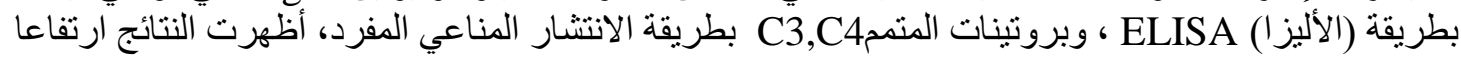

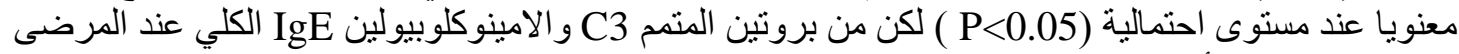

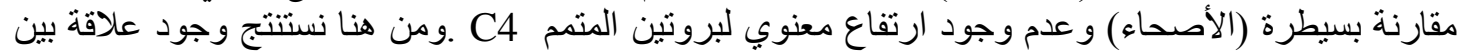

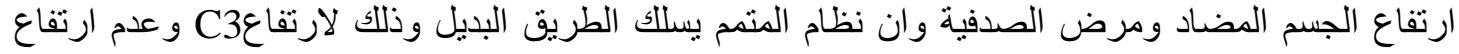

الكلمات المفتاحية :الصدفية بروتين المتمم 3 ، بروتين المتمم 4، الكلوبيولين المناعي IgE 